\title{
The latitudinal distribution of vegetation cover in Siberia
}

\author{
Irina Safronova*, Tatiana Yurkovsksya \\ Komarov Botanical Institute of Russian academy of sciences Professor Popov str., 2, Saint- \\ Petersburg, 197346, Russia
}

\begin{abstract}
The latitudinal changes of vegetation cover on the plains of Siberia are observed. In Western Siberia there are 4 zones (tundra and taiga, and forest-steppe and steppe only here), in Central and North-Eastern Siberia - only 2 zones (tundra and taiga).Tundra zone is represented by 4 subzones in Central Siberia; in Western and North-Eastern Siberia - by 3 subzones (there are no polar subzone). All 5 subzones of the taiga zone are distinguished both in Western Siberia and in the Central Siberia, but in the Central Siberia, forests are found in very high latitudes. The feature of the taiga zone of Western Siberia is high paludification. As a result, the vegetation of mires dominates over the zonal vegetation. Zonal West Siberian types are dark coniferous forests. Light coniferous forests predominate in the taiga zone of Central and North-Eastern Siberia. In the forest-steppe zone in Western Siberia forests are small-leaved - birch, aspen-birch (Betula pendula, Populus tremula). The abundance of mires is the feature of this zone, as well as in the taiga.
\end{abstract}

Taiga forests predominate in Siberia. There is tundra vegetation on the Islands of the Arctic Ocean and on narrow strip along its coast; the steppes occupy a small area in the South of the West Siberian lowland. Latitudinal distribution of vegetation cover in Western, Central and North-Eastern Siberia has its own characteristics, which are determined primarily by differences in climate and geomorphology.

In Western Siberia there are 4 zones: tundra, taiga, forest-steppe and steppe. In Central and North-Eastern Siberia there are only 2 zones: tundra and taiga [1-6].

\section{Tundra zone}

The tundra zone in Western Siberia passes through the Yamal Peninsula, Gydan and the Taz Peninsula. Its southern border reaches the Arctic Circle $\left(66^{\circ} 33^{\prime} 44^{\prime \prime} \mathrm{N}\right)$. In Central Siberia, it occupies the Islands of the Arctic Ocean (Northern Land archipelago, etc.) and the Taimyr Peninsula. The southern border of the zone passes here about $72^{\circ} \mathrm{N}$, so it is further to the North, than in Western Siberia [4, 7]. The tundra zone in North-Eastern Siberia includes the Novosibirsk Islands and the coast of the Arctic Ocean. On the Yano-

\footnotetext{
*Corresponding author : irasafronova@yandex.ru, yurkovskayatat@gmail.ru
} 
Indigir lowland, the southern border of the tundra zone runs approximately $70^{\circ} \mathrm{N}$. In the North of the Kolyma lowland it descends slightly to the South up to $68^{\circ} 30^{\prime} \mathrm{N}$.

The polar tundra subzone (High Arctic tundra) is absent in Western and North-Eastern Siberia. In Central Siberia it is allocated on the Islands of the Arctic Ocean. Herb-lichenmoss spotted and polygonal gravelly tundra communities with Papaver polare ${ }^{*}$, Saxifraga spp., Alopecurus alpinus, Phippsia algida, etc. are common. There are no mires.

In the Northern tundra subzone (Arctic tundra), prostrate low shrubs species (Salix and Dryas) play an important role in the vegetation cover. Salix nummularia is typical in Western Siberia. It does not go to Central Siberia, where the role of other species of willows (S. polaris, S. reptans) increases. Genus Dryas is presented in Western Siberia by D. octopetala, in Central Siberia - D. octopetala and D. punctata, and in North-Eastern Siberia - D. punctata. The role of Cassiope tetragona increases to the East. Mires are sedge-herb-moss; in Western Siberia there are polygonal mires too.

In the middle tundra subzone (Northern hypoarctic tundra) hemiprostrate low shrubs take a significant part in vegetation. In Western Siberia they are Empetrum subholarcticum, Dryas octopetala, Salix nummularia, Cassiope tetragona, Ledum decumbens. In Central Siberia there are Dryas octopetala and D. punctata, Betula nana and B. exilis. In NorthEastern Siberia there are only Dryas punctata and B. exilis; Salix fuscescens appears. The role of Cassiope tetragona and Arctous alpina increases from West to East. There are dwarf shrub-herb-moss low palsa and polygonal mires in Western Siberia, in Central and NorthEastern Siberia mires are polygonal herb- dwarf shrub-lichen-moss.

The southern tundra subzone (South hypoarctic tundra) is characterized by the dominance of shrub tundra. In Western Siberia, it reaches $69^{\circ} \mathrm{N}$ in the North and is bounded by the Arctic Circle in the South. Betula nana and various willows (Salix lapponum, S. phylicifolia, S. dasyclados, S. lanata) are typical for it. In the Central Siberia, this subzone is located much further North and goes from $73^{\circ} \mathrm{N}$ to the South to $69^{\circ} \mathrm{N}$. There are Betula nana and B. exilis; not only Salix glauca, S. lanata, S. pulchra, but also Salix alaxensis, $S$. boganidensis, Duschekia fruticosa are characteristic. In North-Eastern Siberia in the shrub tundra there is only Betula exilis. In willow communities Salix richardsonii participates along with species specified for Central Siberia. Mires are polygonal herb- shrub-lichen-moss; in Western Siberia there are shrub-moss palsa also.

\section{Taiga zone}

In Western Siberia forests have oligodominant structure. Dark coniferous forests predominate, but birch and light coniferous forests are almost equal to them in area. Mires occupy more than $50 \%$ of the area. In Central Siberia, the taiga is very different from the taiga of Western Siberia, primarily by the prevalence of light-coniferous larch forests of Larix gmelinii $[2,3,5]$. In Western and Central Siberia there are 5 subzones, in NorthEastern Siberia - only 2 (there are no subzones of middle, southern taiga and subtaiga).

Subzone of the forest tundra in Western Siberia occupies the area between $67^{\circ} 30^{\prime}$ and $65^{\circ}$ N. In it spruce-larch (Larix sibirica, Picea obovata) open woodlands combined with the shrub-tundra of Betula nana, Salix phylicifolia, S. dasyclados, S. lapponum. In Central Siberia the forest tundra subzone passes through the North Siberian lowland between 70 and $72^{\circ} \mathrm{N}$, i. e. $4-6^{\circ}$ North of Western Siberia. The vegetation is represented by larch (Larix gmelinii, places with Picea obovata) open woodlands in combination with shrub tundra (Betula nana, B. exilis, Duschekia fruticosa). In North-Eastern Siberia the foresttundra includes larch forests not only of Larix gmelinii, as in Central Siberia, but also of $L$. cajanderi. There is no spruce (Picea obovata). Shrub communities are represented by Salix

\footnotetext{
${ }^{\dagger}$ Names of vascular plants are given by S. K. Cherepanov [8].
} 
udensis, S. schwerinii, which are absent in Central Siberia. Dwarf shrub-moss-lichen palsa and ribbed fens (aapa) are mires types. Sphagnum raised bogs are extremely characteristic of Western Siberia.

The subzone of the Northern taiga in Western Siberia passes between $65^{\circ}$ and $62^{\circ} 30^{\prime}-$ $63^{\circ} \mathrm{N}$. The large area is occupied by light coniferous larch and larch-pine (Larix sibirica, Pinus sylvestris) open forests. There is a combination of dwarf shrub-moss-lichen palsa and places ribbed fens (aapa). In Central Siberia the subzone lies to the South $71^{\circ} \mathrm{N}$ up to $65^{\circ} \mathrm{N}$. It is characterized by sparse larch (Larix gmelinii) and spruce-larch (Larix gmelinii, Picea obovata) forests. In North-Eastern Siberia there is no Picea obovata, and in larch forests Larix cajanderi is common, along with L. gmelinii.

The subzone of the middle taiga is in Western and Central Siberia. In Western Siberia it lies between $62-63^{\circ} \mathrm{N}$ and $59^{\circ} \mathrm{N}$. Larch-pine (Pinus sylvestris, Larix sibirica) and pine forests spread in the northern part of the subzone. Spruce-Fir-Siberian pine (Pinus sibirica, Abies sibirica, Picea obovata) forests occupy the southern and south-eastern parts of the subzone. Sphagnum raised bogs are the prevailing type of peatlands. The larch (Larix gmelinii) forests are common in the subzone of the middle taiga in Central Siberia. In the Western part of the subzone (in the basin of the Lower Tunguska and Podkamennaya) the Western species of larch Larix sibirica and dark coniferous species Picea obovata and Pinus sibirica participate in their composition. In the Central part of the Vilyui basin and in the Lena river valley larch forests combined with grass-sedge alas meadows (Carex juncella, Calamagrostis langsdorffii). A characteristic feature of the spatial structure of the vegetation cover is Mari. There are aapa mires to the river Podkamennaya Tunguska.

The subzone of the southern taiga in Western Siberia extends between $63^{\circ}$ and $59^{\circ}-59^{\circ} 30^{\prime} \mathrm{N}$. The characteristic feature of the subzone is the dominance in the dark coniferous forests of Abies sibirica. Sporadically (to the Irtysh river) in these forests Tilia cordata is found. In the South-West, large areas are occupied by pine (Pinus sylvestris) forests. Primary and secondary birch (Betula pendula, B. pubescens c Populus tremula) forests are typical. Almost half of the area of the subzone is occupied by sphagnum bogs, sometimes with the participation of Pinus sibirica or P. sylvestris. Subzone of the southern taiga in Central Siberia stands out in a small space in the basin of the Angara River and reaches $56^{\circ} \mathrm{N}$. Pine (Pinus sylvestris) forests, forests of pine-larch (Larix sibirica) with dark coniferous species Abies sibirica, Pinus sibirica predominate here. There are secondary small-leaved forests (Betula pendula, B. pubescens, Populus tremula).

The subzone of the subtaiga in Western Siberia is a narrow strip between $57^{\circ}$ and $56^{\circ} \mathrm{N}$. Its peculiarity lies in the dominance of small-leaved native and not secondary forests. Predominate birch (Betula pendula), there are aspen-birch and aspen (Populus tremula) forests. The subzone of the subtaiga in Central Siberia goes from North-West to South-East from $57^{\circ} \mathrm{N}$ to $52^{\circ} \mathrm{N}$ along the mountain ranges of Southern Siberia. Pine, larch-pine (Pinus sylvestris, Larix sibirica) forests dominate. Unpatterned fens are the most spread mires type in Western Siberia. Sedge-bryales fens with dwarf birch (Betula exilis) are found in Central Siberia.

\section{Forest-steppe zone}

The forest-steppe zone is situated to the South of $56^{\circ}$ in Western Siberia. Forests are smallleaved - birch, aspen-birch (Betula pendula, Populus tremula). The second component of the zone is meadow steppes. The abundance of mires is a feature of this zone in Western Siberia, as well as in the taiga. In the extreme South-West of Central Siberia there are small isolated relict forest-steppe islands: Achinsk, Krasnoyarsk, Kansk and Balagan-Irkutsk. 


\section{Steppe zone}

The steppe zone is fragmentary and expressed only in Western Siberia, fragmentary. South of $54-55^{\circ} \mathrm{N}$ part of the territory lies within the northern subzone of the herb-feaver-grasses steppes (Stipa zalesskii, Herba stepposa), small areas in the West and East of the region are located in the middle steppe subzone with more xerophytic feather (Stipa lessingiana) steppes.

\section{Conclusion}

So then, in Western Siberia there are 4 zones (tundra, taiga, forest-steppe and steppe, last two are presented only here), in Central and North-Eastern Siberia - 2 (tundra and taiga). Tundra zone is represented by 4 subzones in Central Siberia; in Western and North-Eastern Siberia - by 3 (without polar subzone). All 5 subzones of the taiga zone are distinguished both in Western Siberia and in the Central Siberia, but in the Central Siberia, forests are found in very high latitudes. The feature of the taiga zone of Western Siberia is high paludification. As a result, the vegetation of mires dominates over the zonal vegetation. Dark coniferous forests are zonal West Siberian types. Light coniferous forests predominate in the taiga zone of Central and North-Eastern Siberia. The native birch forests of Betula pubescens and $B$. pendula are the most characteristic feature of Western Siberia only, whereas in other areas they are appearing as a stage of succession. The abundance of mires is the feature of the forest-steppe zone, as well as in the taiga. Sphagnum raised bogs are extremely characteristic of Western Siberia. In Central Siberia, mari is peculiar feature of the spatial structure of the vegetation cover. Forests of Chosenia arbutifolia and Populus suaveolens in floodplains are specific for North-Eastern Siberia.

Work performed under the target topic of the laboratory of Geography and Cartography Vegetation of Komarov Botanical Institute, AAAAA 19-119030690002-5

\section{References}

1. G.V. Krylov, Izvestiya of the Tomsk branch of all-Union Bot. Society, IV (1959)

2. V.B. Sochava (ed.), Ecological-phytocenotic complexes of Asian Russia (the experience of mapping) (Irkutsk, 1977)

3. L.V. Shumilova, Questions of biology (Tomsk, 1978)

4. D.A. Walker (ed), Circumpolar Arctic Vegetation map. S. 1:7,500,000. (CAVM. Team, Anchorage, 2003)

5. E.I. Troeva, M.M. Cherosov, Geobotanical mapping, Saint-Petersburg (2013)

6. T. K.Yurkovskaya, I.N. Safronova, Collana Natura e aree protette, 32 (2017)

7. E.B Pospelova, I.N. Pospelov, Vascular flora of Taimyr peninsula and neighboring territories. Part 1. (Moscow: KMK Scientific Press, 2007)

8. S.K. Cherepanov, Vascular plants of Russia and adjacent states (the former USSR) (Cambridge, 2007) 